\title{
Sanjeev Dhawan,
}

DAV College, India

ORCID ID, 0000-0002-2069-9870

email:dhawan2sanjeev@yahoo.co.in

Afroze Nazneen,

University of Jeddah, Saudi Arabia

ORCID ID, 0000-0003-0843-1000

email: anazneen@uj.edu.sa

Correspondence author: anazneen@uj.edu.sa

\section{INNOVATION APPROACHES TO ESTIMATE FINANCIAL PERFORMANCE OF BANKING SECTOR: THE CASE FOR SAUDI ARABIA}

Abstract. A robust financial structure is considered essential for the swift development and growth and of an economic system. The banking structure is a vital constituent of the financial structure of a nation. The banking system performance assessment is an influential determinant and indicator of the economy's financial strength. Financial Innovation approaches resulting from new technology helps in better estimation of Financial Performances of the banking sector. Banks need to be more closely and accurately watched as they play the role of facilitator of monetary policy of the economy. The prime objective is to examine the financial performance of Saudi Arabia's banking sector through Innovative approaches. With this view, a case study of XYZ Bank has been undertaken. For financial performance evaluation, the CAMEL model has been applied as one of the innovative approaches. This tool is a widely accepted criterion in the field of financial performance evaluation of the banking sector. CAMEL is a ratiosupported mechanism that evaluates bank performance through capital adequacy, quality of assets, management efficiency, quality of earnings, and liquidity. For analyzing the CAMEL model, the various ratios of the model in terms of proxy ratios are given below: For the analysis, nine-year data from 2009 to 2018 has been analyzed using a multiple linear regression model using the SPSS package. The study observed that this innovative approach, i.e., CAMEL specific factors, has mixed influence on the financial performance of XYZ Bank. Capital adequacy and asset quality have a positive effect on bank performance. Moreover, the study also highlights that management efficiency insignificantly affects the profitability of the bank. Moreover, earning quality also signifies a negative influence on profitability. The correlation between asset quality and ROA is negative. It is inferred that those banks with more operating profits and better liquidity management could report high profits. The study further advocates that XYZ Bank must improve its earning quality and management efficiency to come at the same level with the banks having good financial performance and should use innovative methods to estimate financial performance from time to time.

Keywords: capital adequacy, management efficiency, financial innovation, asset quality, liquidity, earning quality, inflation, GDP.

Introduction. A sound economic structure is recognized as essential for the consistent and swift growth of an economy. The banking sector has positively correlated with the nation's economic development (Hussain and Hassan, 2004). The function of the financial system in mobilizing the resources to the other segments of the economy is of imperative significance and cannot be underestimated (Shonekan, 1997). The banking sector supplies the resources from traditional and squat earning sectors to the elevated earning sectors to encourage entrepreneurship (Honohan, 1997). The development of the economic structure may have an affirmative repercussion on the nation's economic growth (Fase and Abma, 2003). An efficient financial system is a prime necessity for a nation's economic development. Hence, the measurement of banking efficiency and their performance in an economy is noteworthy for

Cite as: Dhawan, S., \& Nazneen, A. (2021). Innovation Approaches to Estimate Financial Performance of Banking Sector: The Case for Saudi Arabia. Marketing and Management of Innovations, 2, 252-260. http://doi.org/10.21272/mmi.2021.2-21

252 

Arabia

operational purposes (Berger and Humphhery, 1997). The economic structure executes an immense role in the economic growth of a nation. Moreover, it creates a sturdy correlation among financial structure stability, growth, and economic development (Shaw, 1973). Banks are the basic role model and the foremost basis of funds for the corporate sector and act as principal depository of public savings (Athanasoglou et al., 2008). The banking system significantly impacts the national income growth rate and fosters economic progress by investing in the productive sector (McKinnon, 2010). A sound banking performance repays the investors with a satisfactory yield on investment. A good return speeds up the investment process, which further boosts economic growth (Marshall, 2009).

The financial systems, especially the banks, have to face various risks and uncertainties. In 2008 , the economic downturn outcome in bank failures was elicited in the USA. Then, it rapidly spread across the globe. Hence, banks urgently need to examine their financial performance (Sundararajan et al., 2002). Researchers and academicians tried to evaluate the banking performance employing the CAMEL model during the different spans and perspectives. External and internal determinants may influence the performance of banks. The internal factors include banks' specific features that are mainly impacted by the board and management resolutions (Hassan Al-Tamimi, 2010). Among various Financial Innovative approaches employed for estimating the Banking sector's performance, the CAMEL rating is one of the trusted and universally acceptable models. The CAMEL rating model is the most effective accepted tool among the regulators and researchers as the other performance mechanisms in the banking sector are extremely volatile to the market factors (Gaytán and Johnson, 2002). The regulators have boosted the banking sector evaluation by employing the CAMEL model (capital adequacy, asset quality, management quality, earnings, and liquidity) rating mechanism to evaluate the performance and financial soundness of the bank's operations. Several studies examined the bank financial performances based on CAMEL methodology, which is one of the innovative approaches which used bank-specific determinants that have an impact on the overall performance of the banking sector Aspal and Malhotra (2013); Aspal and Dhawan (2014); Kumar and Kumar (2013) and Chantapong (2005). The current study primarily evaluates the financial performance of XYZ Bank by applying the Innovation approaches to estimate the financial performance of the banking sector. For this purpose CAMEL model is used.

Literature Review. Researchers and academicians investigated the performance of the banking sector by employing the CAMEL model, and a summary of some imperative studies has been discussed. Sundararajan et al. (2002) opined that the banks are highly exposed to a diversity of risks arising in the dynamic business environment. The economic bankruptcy of US banks elicited in 2008 and then violently spread across the globe, which advocated the need to evaluate the banking performance. Hirtle and Lopez (1999) emphasized that the rating provided by the CAMEL model about the banks is highly confidential and applied by management for the projection of business strategies. Bodla and Verma (2006) suggested that the CAMEL rating tool facilitates the Central Bank of India to classify the banks that working requires special supervision from various factors and take corrective measures to improve. Bernanke (2007) found that U.S. Federal bank scrutinized the soundness and safety of banks' financial strength using the CAMEL model for on-site bank assessment. Wirnkar and Tanko (2008) investigated the competence of CAMEL in the assessment of banks' performance. They observed the plumpness of each constituent of the CAMEL model in assessing the overall bank performance and eventually extract the best ratios that could be adopted in evaluating the bank's competence. Christopoulos et al. (2011) revealed that financial findings of the Lehman Brothers bank highlighted that its loans were found as doubtful and bad. In addition, the management did not conform to the supervisory rules; moreover, the risk management techniques were not sufficient. Eventually, the supervisory team could not predict declining signs of the bank. Dahiyat (2012) developed a rating system primarily based on the CAMELS' banking rating system to investigate the performance of Jordanian brokerage firms. Such a framework may serve supervisory bodies and represent the first step towards instituting a comprehensive ranking system for brokerage firms. 

Arabia

In a study, the CAMEL mechanism was employed by (Said and Saucier, 2003) to examine the capital adequacy, efficiency, earnings capability, solvency, and liquidity strength of Japanese banks. In a study of Bangladesh, Sarker (2005) used CAMEL rating for the supervision and assessment of Islamic banks. The study's findings facilitated the regulators to establish a Shariah benchmark for the assessment and supervision of Islamic financial institutions and banks. Aburime (2008) surveyed the profits determinants of 33 Nigerian banks and revealed that credit range, size of capital, and ownership are significantly concerned with banks' profits. A study on Nigerian banks' performance Alabede (2012) highlighted that in the worldwide financial conditions impact, market concentrations and assets quality are the essential factors of profitability. The study revealed that banks should lessen their NPAs and encourage fair competition among them. In India, Aspal and Malhotra (2013), using the CAMEL Model, found that the Bank of Baroda attained the first rank owing to its enhanced asset quality and liquidity. Whereas, United Bank of India earned the lowest rank due to poor earning and assets and management inefficiency. Similarly, a study by Kumar and Kumar (2013) applied CAMEL rating methodology to assess the State Bank of India group performance and found that banks are required to improve their asset quality and capital adequacy. Malhotra and Aspal (2014) used the CAMELS model to examine the economic performance of the Indian banks. They found that Kotak Mahindra Bank attained the first rank, followed by Axis Bank, while ICICI Bank attained the lowest performance. Aspal and Dhawan (2014) assessed the working of Indian old private banks and found that the independent variables capital adequacy and asset quality became statistically insignificant. Other independent variables such as management efficiency, earning quality, liquidity and sensitivity are statistically significant, indicating their effect on profitability. Aspal and Dhawan (2014) assessed the performance of Indian old private banks and revealed that Federal Bank, Nainital Bank, and Tamilnad Mercantile Bank performed excellently. In contrast, ING Vysya Bank, Catholic Syrian Bank, and Dhanalakshmi Bank performed the worst. Objectives of the Study. Given the literature discussion, the prime aim is to examine the effect of CAMEL determinants on the performance of XYZ Bank, Saudi Arabia.

Methodology and research methods. The nature of the current study is descriptive and analytical. Secondary data is used, and the same has been obtained from the published financial statement of XYZ Bank, Saudi Arabia. The period of study of the banking sector is nine years, from 2009-2018, as this is the most recent available data. The multiple linear regression model is employed to investigate the relative significance of banks' specific variables in affecting the financial bank performance. The review has been made from the research studies of fa ew journals and articles. Because of the Ethical constraint, the actual name of the Bank was hidden. This study called it XYZ Bank.

The prime bank's purpose is to earn profits to sustain the economy and meet the nation's requirements. Intending to accomplish this crucial objective, the bank tracks different strategies and executes a wide range of activities. Researchers and investigators have applied various kinds of financial ratios to assess the profitability of banks. On reviewing the literature, it has come to know that among the different ratios determining bank profitability, Return on Assets (ROA) is a significant ratio (Berger, 1995; Naceur, 2003; Flamini et al., 2009; Khrawish and Khraiwesh, 2011; Aspal and Dhawan, 2017; Aspal et al., 2019). For this study, the proxy ratio return on assets is applied to evaluate the bank's performance. Explanation of CAMEL Variables and Hypotheses Formation. The CAMEL model tool is the widely accepted criteria in the banking sector's financial performance evaluation. CAMEL is a ratio-supported mechanism that evaluates bank performance through capital adequacy, quality of assets, management efficiency, quality of earnings, and liquidity. For analysis of the CAMEL model, Table 1 gives the various ratios of the model in terms of proxy ratios.

Capital adequacy highlights the bank's internal potency to face up fatalities during a financial crunch (Dang, 2011). It has a directly proportional relationship to the bank buoyancy during the financial crisis 
S, Dhawan, A., Nazneen. Innovation Approaches to Estimate Financial Performance of Banking Sector: the Case for Saudi Arabia

period and directly influences bank profits by undertaking risky but profitable projects (Sangmi and Nazir, 2010).

Table 1. The ratios of the proposed model

\begin{tabular}{ll}
\hline \multicolumn{1}{c}{ Ratio } & \multicolumn{1}{c}{ Proxy Ratio Measurement } \\
\hline Capital Adequacy (C) & Capital to Risk-weighted Assets \\
Asset Quality (A) & Non-Performing Assets to Total Assets \\
Management Efficiency (M) & Net-Profit per Branch \\
Earning Quality (E) & Operating - Profit to Total Assets \\
Liquidity (L) & Total - Loans to Total Assets \\
\hline \multicolumn{2}{c}{ Sources: developed by the authors }
\end{tabular}

Sources: developed by the authors.

The mandate CAR ratio is 8 percent as per international standards. Aspal and Nazneen (2014) investigated the capital adequacy of the Indian banks. The authors revealed that private sector banks own additional resources to fulfill their obligations and could afford more advances to the market by defending the owner's stake. In the light of the above literature, the following hypothesis has been framed:

$\mathrm{H1}$ : Capital Adequacy has no statistically significant impact on profitability (ROA).

The banks' asset quality reflects the quality of assets it possesses and its financial potency. The assets quality assesses the element of non-performing assets amid the total loans and advances disbursed to the public and other institutions. Poor quality of assets is identified as a cause of capital erosion and credit $\&$ capital risks (Mwega, 2009). The problem of escalating NPAs is a confrontation with the banking system, which would adversely influence the bank's performance (Rajender, 2009). In the light of the above literature, the following hypothesis has been framed:

$\mathrm{H} 2$ : Asset Quality has no statistically significant impact on profitability (ROA).

The efficiency of the management is also a fundamental constituent of the CAMEL method that guarantees the continued banks' growth and existence. Management performance is generally qualitatively assessed through subjective measurements, employees' quality, managerial discipline, and control system (Sangmi and Nazir, 2010). In the light of the above literature, the following hypothesis has been framed:

H3: Management Efficiency has no statistically significant impact on profitability (ROA).

The earning quality component of CAMEL reflects the income quality of banks. High earning quality should reflect the banks' present and future operating performance (Dechow and Schrand, 2004). The operating profit ratio evaluates the organization's capability to maintain revenue escalation in the future (Sarkar et al., 2008). In the light of the above literature, the following hypothesis has been framed:

H4: Earning Quality has no statistically significant impact on profitability (ROA).

Liquidity is an indispensable feature that reveals the bank's capability to fulfill its current commitments and sustain ample liquid assets. Liquidity is the capability degree of a bank to fulfill its commitments (Duttweiler, 2011). A satisfactory liquidity level has a positive impact on bank profits (Dang, 2011). In the light of the above literature, the following hypothesis is framed:

H5: Liquidity has no statistically significant impact on profitability (ROA).

In the study, the dependent variables are banks' financial performance and return on asset ratio. The CAMEL specific explanatory variables such as capital adequacy, asset quality, management efficiency, earning quality, and liquidity are proxied by Capital to risk-weighted assets ratio (CRAR), Non-performing assets to total assets ratio, Net profit per branch ratio, the ratio of operating profit to total assets and ratio of total loans to total assets Ratio. The multiple regression model is as follows:

$$
\text { ROAit }=\alpha 0+\beta 1 C R A R i t+\beta 2 A Q i t+\beta 3 M E i t+\beta 4 E Q i t+\beta 5 L Q i t+e_{\mathrm{i}}
$$



Arabia

where $\mathrm{ROA}_{\mathrm{it}}=$ Indicator of Financial Performance; $\mathrm{a}_{0}=$ Intercept term; CRARit $=$ Bank's Capital Adequacy; $A Q_{i t}=$ Bank's Asset Quality; $M E_{i t}=$ Bank's Management Efficiency; $E Q_{i t}=$ Bank's Earning Quality; LQit= Bank's Liquidity; eit= Stochastic error term.

Results. Table 2 highlights the descriptive results of variables that influence the bank's financial performance. The average Capital Adequacy Ratio of XYZ Bank is 18.43, which is higher than the statutory requirement of $8 \%$. It means the bank could tackle the market, credit, and operational risks to soak up the potential losses and shield the debtors.

Table 2. Descriptive Statistics

\begin{tabular}{lcc}
\hline \multicolumn{1}{c}{ Variables } & Observations & Mean \\
\hline Capital Adequacy & 9 & 18.43 \\
Asset Quality & 9 & 1.30 \\
Management Efficiency & 9 & 22.64 \\
Earning Quality & 9 & 2.05 \\
Liquidity & 9 & 52.52 \\
\hline
\end{tabular}

Sources: developed by the authors.

The average asset quality of the XYZ Bank proxied by NPA to total assets ratio is 1.30 percent. It signifies the exposure to the risk of credit and its relationship with the banks' profitability is expected to be negative. An additional significant CAMEL-specific variable is management efficiency. The present study has been measured by Net Profit per Branch Ratio, which is 22.64 percent on average. The high value of the ratio designates the good efficiency of the bank.

In contrast, the earning quality average ratio came to be 2.05 percent. Another fundamental variable affecting banks' profitability is liquidity, and the ratio for the same is 52.52 percent. The high liquidity ratio reflects that the bank has sufficient liquidity to acknowledge unforeseen funding requirements. The problem of multicollinearity is analyzed from Table 3. Cooper et al. (2009) opined correlation score of 0.8 or more reflects the problem of multicollinearity. From Table 2, it could be concluded that there is the problem of multicollinearity regarding the relationship between profitability \& management efficiency and between profitability \& earning quality. The results from correlation analysis depict that profitability (ROA) is negatively correlated with asset quality, i.e., there is a negative correlation between profitability (ROA) and NPA to Total assets ratio. However, management efficiency, capital adequacy, earnings quality, and liquidity positively correlate with bank profitability.

Table 3. Correlation table

\begin{tabular}{lrrrrrrr}
\hline Variables & ROA & CAR & \multicolumn{2}{c}{ AQ } & ME & EQ & LQ \\
\hline ROA & 1.000 & 1.000 & 1.000 & 1.000 & 1.000 & 1.000 \\
CAR & 0.251 & 0.430 & $-0.848^{*}$ & $0.876^{*}$ & $0.772^{*}$ & \\
AQ & -0.666 & -0.025 & -.0584 & $0.819^{*}$ & & \\
ME & $0.914^{*}$ & 0.294 & -0.489 & & & \\
EQ & $0.927^{*}$ & 0.413 & & & & \\
LQ & $0.766^{*}$ & & & & & &
\end{tabular}

*/ndicates correlation significant at level $5 \%$

Sources: developed by the authors.

The effect of CAMEL-specific variables on the performance of XYZ Bank is depicted in Table 4. The regression findings are estimated using the null hypotheses that the CAMEL-specific variables have not 

Arabia

significantly influenced the XYZ bank performance. The alternative hypothesis framed signifies that the CAMEL proxy ratios have significantly impacted the bank's financial performance.

Table 4. ROA as Dependent Variable

\begin{tabular}{lclllll}
\hline Explanatory Variables & Constant & CAR & $\mathrm{AQ}$ & $\mathrm{ME}$ & $\mathrm{EQ}$ & $\mathrm{LQ}$ \\
\hline$\beta_{i}$ & 0.075 & $0.068^{*}$ & $0.060^{*}$ & 0.026 & $-0.021^{*}$ & 0.222 \\
$\mathrm{t}$-values & $(0.676)$ & $(0.015)$ & $(0.023)$ & $(0.717)$ & $(0.021)$ & $(0.188)$ \\
& 14.290 & 4.074 & 3.611 & .389 & 3.679 & 1.585 \\
$\mathrm{R}^{2}$ & 0.993 & & & Adj. $\mathrm{R}^{2}$ & $=0.984$ & \\
F-Test & 115.137 & & & Durbin Watson $=2.177$ & \\
\hline
\end{tabular}

${ }^{*}$ Statistically significant at the $5 \%$ level

Sources: developed by the authors.

The regressions findings reveal that adjusted $\mathrm{R} 2$ is 0.984 , which signifies the good fit of regression. In the case of CAMEL-specific variables as Capital adequacy (CAR), Asset Quality (AQ), and Earning Quality (EQ), the null hypotheses $\mathrm{H} 1, \mathrm{H} 2$, and $\mathrm{H} 4$ are rejected at a $5 \%$ significance level. It reveals that these three variables have a significant influence on the financial performance measured with the help of ROA. The other variables, such as Management Efficiency (ME) and Liquidity (LQ), are statistically insignificant, which leads to the acceptance of null hypotheses $\mathrm{H} 3$ and $\mathrm{H} 5$.

It implies that efficiency of management and liquidity do not significantly impact bank performance. In the analysis, return on assets is employed as an indicator of bank performance. The same variable was used by Alabede (2012) to analyze the influence of the global financial conditions on the Nigerian banks' performance. In the present study, regression analysis reveals that capital adequacy ratio is positively correlated to ROA and statistically significant, implying that the results support the alternative hypothesis H1. Thus findings are consistent with the results of (Berger, 1995; Naceur, 2003; Aburime, 2008; Athanasoglou et al., 2008) opined that the capital adequacy ratio has positively influenced bank profits. Further, the quality of assets has significantly and positively impacted the bank's profits. Moreover, the ROA is negatively correlated with asset quality; these findings are not in line with the results of (Flamini et al., 2009), who found a positive correlation between Asset quality and ROA. But, the current results concur with (Olweny and Shipho, 2011) findings on the Kenyan banks. These results signify that the increment in non-performing assets would result in a fall in the bank's financial performance. In addition, the independent variable management efficiency has an insignificant relationship with Return on Assets (ROA). It implies that in the present study, financial performance is not influenced by management efficiency in the case of XYZ Bank. The study's results concur with Ongore and Kusa (2013) study, who suggested a positive association between management efficiency and Return on Assets.

In addition, the association between earning quality and ROA came out to be positive and statistically significant at a 5 percent considerable level that is in concurrence with the results of the positive correlation between operating profits and return on assets by Flamini et al. (2009). The liquidity management has no statistically significant association with ROA and leads to the rejection of the alternative hypothesis. It signifies that liquidity did not influence the profitability of the bank. The results are similar to Ongore and Kusa (2013) for Kenya's commercial banks, where liquidity has an insignificant impact on ROA.

Conclusions. The findings of the present study highlight that the CAMEL specific factors have mixed influence XYZ Bank's financial performance. The association between capital adequacy and financial performance is found to be positive and significant. The results align with Berger (1995), who observed a positive linkage between capital and bank performance. The results further highlight that asset quality has a significant and positive association with the bank's profitability. But, the correlation between asset quality and ROA is negative, which aligns with Kamau (2009) and Elyor (2009) studies. It reflects that poor asset quality is the cause of the poor financial performance of the bank. 

Arabia

Consequently, it could be concluded that banks having good asset quality and fewer NPAs are more capable of earning high profits. In addition to this, management efficiency has an insignificant relationship with the profitability of banks. Furthermore, earning quality has a significant but negative impact on profits, whereas liquidity has an insignificant influence on the bank's financial performance. From, this it is inferred that those banks with more operating profits and better liquidity management could report high profits. From this study, it could be concluded that CAMEL-specific variables impact XYZ Bank's financial performance. The findings suggest that $X Y Z$ Bank should focus on earning quality to speed up its pace at par with other banks having sound economic performance.

Author Contributions: conceptualization, A. N., and S. D.; methodology, A. N.; validation, A. N.; resources, S. D.; data curation, S. D.; writing-original draft preparation, S. D.; writing review and editing, A. N .; visualization, S. D.; supervision, A. N.; project administration, A. N. and S. D.

Funding: This research received no external funding.

\section{References}

Aburime, T. (2008). Determinants of bank profitability: company-level evidence from Nigeria. SSRN 1106825. [Google Scholar] [CrossRef]

Alabede, J. O. (2012). The intervening effect of global financial condition on the determinants of bank performance: Evidence from Nigeria. Accounting and Finance Research, 1(2), 161-176. [Google Scholar]

Aspal, P. K., \& Dhawan, S. (2014). Financial performance assessment of banking sector in India: A case study of old private sector banks. The Business \& Management Review, 5(3), 196. [Google Scholar]

Aspal, P. K., \& Malhotra, N. (2013). Performance Appraisal of Indian Public Sector Banks. World Journal of Social Sciences, 3(3), 71 - 88. Retrieved from [Link]

Aspal, P. K., \& Nazneen, A. (2014). An empirical analysis of capital adequacy in the Indian private sector banks. American Journal of Research Communication, 2(11), 28-42. [Google Scholar]

Aspal, P. K., Dhawan, S., \& Nazneen, A. (2019). Significance of bank specific and macroeconomic determinants on performance of Indian private sector banks. International Journal of Economics and Financial Issues, 92), 168. [Google Scholar]

Athanasoglou, P. P., Brissimis, S. N., \& Delis, M. D. (2008). Bank-specific, industry-specific and macroeconomic determinants of bank profitability. Journal of international financial Markets, Institutions and Money, 18(2), 121-136. [Google Scholar] [CrossRef]

Berger, A. N. (1995). The profit-structure relationship in banking--tests of market-power and efficient-structure hypotheses. Journal of Money, Credit and Banking, 272), 404-431. [Google Scholar] [CrossRef]

Berger, A. N., \& Humphrey, D. B. (1997). Efficiency of financial institutions: International survey and directions for future research. European journal of operational research, 98(2), 175-212. [Google Scholar] [CrossRef]

Bernanke, B. S. (2007). Central banking and bank supervision in the united states (No. 250). [Google Scholar]

Bodla, B. S., \& Verma, R. (2006). Evaluating performance of banks through CAMEL Model: A case study of SBI and ICICI. The IUP Journal of Bank Management, (3), 49-63. [Google Scholar] []

Chantapong, S. (2005). Comparative study of domestic and foreign bank performance in Thailand: The regression analysis. Economic Change and Restructuring, 38(1), 63-83. [Google Scholar] [CrossRef]

Christopoulos, A. G., Mylonakis, J., \& Diktapanidis, P. (2011). Could Lehman Brothers' collapse be anticipated? An examination using CAMELS rating system. International Business Research, 4(2), 11. [Google Scholar]

Cooper, D. R., Schindler, P. S., \& Sun, J. (2009). Business research methods. New York: McGraw-Hill Irwin. [Google Scholar] Dahiyat, A. (2012). The Application of CAMELS rating system to Jordanian brokerage firms. International Research Journal of Finance and Economics, 88, 16-23. [Google Scholar]

Dang, U. (2011). The CAMEL rating system in banking supervision. A case study. [Google Scholar]

Dechow, P. M., \& Schrand, C. M. (2004). Earnings quality. Charlottesville, VA: Research Foundation of CFA Institute. Retrieved from [Link]

Duttweiler, R. (2011). Managing liquidity in banks: a top down approach. John Wiley \& Sons. [Google Scholar]

Elyor, S. (2009). Factors affecting the performance of foreign banks in Malaysia(Doctoral dissertation, Universiti Utara Malaysia).

Fase, M. M. G., \& Abma, R. C. N. (2003). Financial environment and economic growth in selected Asian countries. Journal of Asian Economics, 14. [Google Scholar] [CrossRef]

Flamini, V., McDonald, C. A., \& Schumacher, L. B. (2009). The determinants of commercial bank profitability in Sub-Saharan Africa. IMF Working Papers, 1-30. [Google Scholar] 
Gaytán, A., \& Johnson, C. A. (2002). A review of the literature on early warning systems for banking crises (Vol. 183). Central Bank of Chile. [Google Scholar]

Gujarati, D. N. (2009). Basic econometrics. Tata McGraw-Hill Education. Retrieved from [Link]

Hassan Al-Tamimi, H. A. (2010). Factors influencing performance of the UAE Islamic and conventional national banks. Global Journal of Business Research, 4(2), 1-9. [Google Scholar]

Hirtle, B., \& Lopez, J. A. (1999). Supervisory information and the frequency of bank examinations. Economic Policy Review, 51). [Google Scholar]

Honohan, P. (1997). Banking system failures in developing and transition countries: Diagnosis and predictions (No. 39). Bank for International Settlements. [Google Scholar] [CrossRef]

Hussain, M., \& Hassan, M. K. (2005). Basel Capital Requirements and Bank Credit Risk Taking In Developing Countries (No. 2005-01). University of New Orleans, Department of Economics and Finance. [Google Scholar]

Kamau, A. W. (2009). Efficiency in the Banking Sector: An Empirical Investigation of Commercial Banks in Kenya. A thesis submitted in partial fulfillment of the Requirements of Nairobi University for the Degree of Doctor of Philosophy. Nairobi: University of Nairobi. Retrieved from [Link]

Khrawish, H. A., \& Khraiwesh, A. H. A. (2011). Determinants of commercial banks performance: Evidence from Jordan. International Research Journal of Finance and Economics, 81(1), 148-159. Retrieved from [Link]

Kumar, M. S., \& Kumar, A. P. (2013). A CAMEL model analysis of state bank group. World Journal of Social Sciences, 3(4), 36-55.

Malhotra, N., \& Aspal, P. K. (2014). Performance Measurement of New Private Sector Banks in India. The Indian Journal of Commerce A Quarterly Refereed Journal, 26. [Google Scholar]

Marshall, J. (2009). The financial crisis in the US: key events, causes and responses. House of Commons Library. Retrieved from [Link]

McKinnon, R. I. (2010). Money and capital in economic development. Brookings Institution Press. [Google Scholar]

Mwega, F. M. (2009). Global financial crisis discussion series. Overseas Development Institute, 111. [Google Scholar]

Naceur, S. B. (2003). The determinants of the Tunisian banking industry profitability: Panel evidence. Universite Libre de Tunis working papers, 10, 2003. [Google Scholar]

Olweny, T., \& Shipho, T. M. (2011). Effects of banking sectoral factors on the profitability of commercial banks in Kenya. Economics and Finance Review, 1(5), 1-30. [Google Scholar]

Ongore, V. O., \& Kusa, G. B. (2013). Determinants of financial performance of commercial banks in Kenya. International journal of economics and financial issues, 3(1), 237. [Google Scholar]

Rajender, K. (2009). Management of non-performing assets in public sector banks. The Indian Journal of Commerce, 62(1), 45-54. [Google Scholar]

Said, M., \& Saucier, P. (2003). Liquidity, solvency, and efficiency: An empirical analysis of the Japanese banks' distress. Journal of Oxford, 5(3), 354-358. [Google Scholar]

Sangmi, M. U. D., \& Nazir, T. (2010). Analyzing financial performance of commercial banks in India: Application of CAMEL model. Pakistan Journal of Commerce and Social Sciences (PJCSS), 4(1), 40-55. [Google Scholar]

Sarkar, J., Sarkar, S., \& Sen, K. (2008). Board of directors and opportunistic earnings management: Evidence from India. Journal of Accounting, Auditing \& Finance, 23(4), 517-551. [Google Scholar] [CrossRef]

Sarker, A. (2005). CAMELS rating system in the context of Islamic banking: A proposed 'S'for Shariah framework. Journal of Islamic Economics and Finance, 1(1), 78-84. [Google Scholar]

Shaw, E. S. (1973). Financial deepening m economic development. Oxford Universtty Press, New York. [Google Scholar]

Shonekan, E. A. (1997). The relevance of financial sector to Vision 2010. The Nigerian Banker, 1, 17. [Google Scholar]

Sundararajan, V., Enoch, C., San Jose, A., Hilbers, P., Krueger, R., Moretti, M., \& Slack, G. (2002). Financial soundness indicators: analytical aspects and country practices (Vol. 212). Washington, DC: International Monetary Fund. [Google Scholar]

Wirnkar, D., \& Tanko, M. (2008). CAMEL (S) and Banks Performance Evaluation: The Way Forward, viewed 5 August 2014. [Google Scholar]

Санджеєв Даван, Коледж DAV, Індія

Афрозе Назнін, Університет Джидди, Саудівська Аравія

Інноваційні підходи оцінювання фінансової ефективності банківського сектору: досвід Саудівської Аравії

Банківська система є основою фінансової структури країни та основою ї̈ економічного зростання. Авторами зазначено, що оцінювання результативності функціонування банківської системи дозволяє своєчасно визначити відхилення від таргетованих значень економічного розвитку країни. При цьому в сучасних глобалізаційних умовах необхідним $\epsilon$ розроблення та застосування інноваційних підходів оцінювання фінансової ефективності банківського сектору. У статті наголошено, що банківська система виступає детермінантою монетарної політики країни. 3 огляду на це, необхідним $є$ забезпечення постійного контролю ефективності його функціонування. Головною метою дослідження $є$ оцінювання фінансової результативності функціонування банківського сектору Саудівської Аравії з використанням інноваційних підходів. Oб'єктом дослідження є банк умовно названий «XYZ». Для досягнення поставленої мети застосовано інноваційну модель 
S, Dhawan, A., Nazneen. Innovation Approaches to Estimate Financial Performance of Banking Sector: the Case for Saudi Arabia

CAMEL, яка є широко розповсюдженим підходом оцінювання фінансових результатів діяльності банківського сектору за критеріями достатності капіталу, якості активів, ефективності управління, якості доходів та ліквідності. Практичну реалізацію дослідження здійснено з використанням пакету програмного забезпечення SPSS Statistics. Емпіричне дослідження проведено за допомогою методу множинної лінійної регресії. Вихідні дані для дослідження сформовано за $2009-2018$ роки. За результатами дослідження встановлено фактори моделі CAMEL, які мають неоднозначний вплив на фінансові результати діяльності банку XYZ. Зокрема, достатність капіталу та якість активів позитивно впливають на фінансову результативність банку. Авторами зазначено, що ефективність менеджменту в банку має статистично значущий вплив на його прибутковість, а змінна «якість доходів» має негативний вплив. Отримані результати свідчать про негативне співвідношення між якістю активів та рентабельністю інвестицій. На основі проведеного дослідження, авторами визначено, що банки 3 вищим операційним прибутком та ефективнішою системою управління ліквідністю мають вищу прибутковість. Враховуючі результати дослідження у статті запропоновано напрями підвищення ефективності діяльності банку XYZ, а саме: диверсифікація джерел доходів; підвищення ефективності управління; впровадження інноваційних методів оцінювання фінансових результатів діяльності банку.

Ключові слова: достатність капіталу, ефективність управління, фінансові інновації, якість активів, ліквідність, якість прибутків, інфляція, ВВП. 